\section{The Atlantic Cod and its Races.*}

\section{$\mathrm{D}$}

. JOHS. SCHMIDT'S happy intuition as to the choice of successful investigations is again exemplified by his latest memoir. Here he has examined samples of cod from all over its north Atlantic region of distribution. In each fish (about 20,000 in all) the numbers of vertebræ and the numbers of rays in the second dorsal fin have been counted. The results are fully displayed in a series of tables and charts. They are very remarkable and unexpected.

The highest numbers of vertebrae $(54$ to 55.46$)$ are found in the cod taken from the sea off the coasts of Newfoundland and Labrador, and the lowest numbers are those found in Irish Sea fish; we may summarise these results : Newfoundland, Labrador
Greenland, Iceland, East Baltic from 'scotland, North Sea from Scot Rockall, West fro
54-55.46 Vert. Temperature $0^{\circ}-5^{\circ}$

$\begin{array}{cccc}52.41-53.99 & , & & 5^{\circ}-10^{\circ} \\ 52-52.4 & , & , & 5^{\circ} \text { to }>10^{\circ} \\ 51.47 .51 .99 & , & , & 10^{\circ}-15^{\circ}\end{array}$

Thus there is an undoubted correlation between the values of a certain morphological character and the general sea temperatures throughout the whole region inhabited by the cod. Dr. Schmidt gives other examples of similar correlations : (I) in respect of the number of rays in the second dorsal fin of the cod; (2) the numbers of vertebræ in both winter and summer spawning herrings; and (3) the numbers of vertebræ in the fish Zoarces. The latter investigation was the subject of a previously published memoir and it is very interesting : in a single fiord, for example, the numbers of vertebræ in the fish diminished regularly from the shore regions immediately outside the fiord to those at its inner extremity.

Returning to the cod results, it is clear that there are local races with relatively restricted regions of distribution, and that there cannot be much intermigration between these localised regions. This probably applies also to the distribution of the herring. The conditions responsible for these segregations require investigation, and Dr. Schmidt only touches this question. Probably there is 'direct impression', or action, upon the developmental factors of the fish, during some 'critical period., by the external physical factors. Certain experimental results actually suggest this; but, obviously, much more investigation is required. Such a conclusion does not rule out the hypothesis that differences between the races are of a " hereditary, genotypical nature". It is, on the whole, improbable that the differences are due to selection of the variates. Dr. Schmidt's memoir is a model of clear and accurate exposition, and the results themselves are of unusual interest.

J. J.

- Comptes-rendus des travaux du Laboratoire Carlsberg, vol, 18, No. 6. - Racial Investigations, 10: The Atlantic Cod (Gadus callarias, L.) and Local Races of the same." By Johs. Schmidt. Pp. $722+10$ plates.

\section{University and Educational Intelligence.}

Cambridge.-The Appointments Committee of the Faculty of Biology " $\mathrm{B}$ " has reappointed Dr. W. E. Dixon to be University lecturer in biochemistry, and has appointed Mr. E. T. C. Spooner, of Clare College, and Mr. A. A. Miles, of King's College, to be University demonstrators in pathology.

The following Grace has passed the Senate: "That the Degree of Master of Arts, honoris causa, be con- ferred upon Ebenezer Everett, for many years assistant to Professor Sir J. J. Thomson at the Cavendish Laboratory."

The Cecil Peace Prize of $£ 100$, which is offered yearly for an essay on some subject connected with the maintenance of international peace, to any undergraduate of any university or university college in Great Britain or Northern Ireland who has not attained the age of twenty-five years, has been awarded to $\mathrm{Mr}$. G. G. Thomson (University of Edinburgh) for 1930 , with Freda Marrison (University College of Swansea) as proxime accessit.

The annual meeting of the Association of Technical Institutions will be held in the Merchant Taylors' Hall, Threadneedle Street, London, E.C.2, on Friday and Saturday, Feb. 27 and 28 . The proceedings will commence at 11 A.M. on Feb. 27, when the chair will be taken by the president, the Right Hon. Lord Eustace Percy, M.P., who will introduce the presidentelect, Major-General Sir Philip Nash. Following this, an address will be given by Principal B. Mouat Jones. on "Technical Education in Russia". Members and guests of the Association will afterwards be received by the Master and Wardens of the Merchant Taylors' Company, and luncheon will be served in the Company's Hall. Friday afternoon and Saturday morning will be devoted to the reading of papers by Mr. G. H. Gater, Chief Education Officer, London County Council, on "A Descriptive Account of Technical Education in London" ; Mr. Comyns Carr, on "Industrial Administration"; Principal J. A. Todd, of the City School of Commerce, Liverpool, on "National Certificates in Commerce"; Mr. J. W. Ramsbottom, Director, City of London College, on "Commercial Education in America".

THE report of a consultative committee, under the chairmanship of Sir W. H. Hadow, which was appointed by the Board of Education to inquire into the courses of study suitable for children (other than children in infants' departments) up to the age of eleven years, with special reference to the needs of children in rural areas, has just been published under the title of "The Primary School" (London: H.M. Stationery Office, 1931. 2s. 6d. net). The report may be regarded as the logical complement to the consultative committee's report on the "Education of the Adolescent" (1926) (Hadow Report), dealing as it does with the upper stage of primary education. This important period in the development of children has, up to the present, been comparatively neglected by physiologists and psychologists. Recognising this fact, the Consultative Committee obtained memoranda on the physical growth and mental development of children up to the age of eleven years from Prof. H. A. Harris and Prof. Cyril Burt. The data contained in these memoranda (Appendices 2 and 3) and in other evidence obtained from various specialists are discussed in Chaps. 2 and 3. Chap. 4 deals with administrative problems, while Chap. 5 discusses questions of the internal organisation of primary schools. Chap. 6, on the problem of retarded children at the primary stage of education, dealing especially with the chief causes of retardation, should be of considerable interest to teachers and administrators. Chap. 7 gives the views of the Committee on the general problem of the curriculum for children up to the age of eleven. The sections on the "Study of Nature ", and the memorandum on the anatomical and physiological characteristics and development of children between the ages of seven and eleven, by Prof. H. A. Harris, and that on the mental characteristics of such children, by Prof. Cyril Burt, are of special interest. 